\title{
Effects of a Sport Education Intervention on Students' Self-Esteem and Sport Confidence in University Badminton Classes
}

\author{
Hosung So ${ }^{1}$, Taemin $\mathrm{Ha}^{2}$, Hyeonho $\mathrm{Yu}^{3}, \&$ Christopher Gentry ${ }^{1}$ \\ 1 California State University, San Bernardino \\ 2 University of Northern Colorado \\ 3 Arizona State University
}

\section{Introduction}

Sport education curriculum model (SEM) is a curriculum, unit, or method of teaching used in physical education programs, and has three major goals for students to become competent, literate, and enthusiastic players (Siedentop, Hastie, \& van der Mars, 2020). Alexander and Luckman (2001) described that the SEM offers an extended season, persisting groups, less direct teaching, and more responsibility for students which can create meaning, purpose, and enjoyment for students in physical education.

Self-confidence is recognized as vital to both development and performance enhancement (Weinberg \& Williams, 1993; Feltz, 1988). The term self-confidence refers to one's belief that he or she can successfully execute a desired behavior. Self-esteem is the extent to which an individual likes, values, and accepts the self (Schacter, Gilbert, \& Wegner, 2009) and is related to self-confidence, and pertains to one's personal judgement of worthiness. Compared with people with low self-esteem, those with high self-esteem tend to live happier and healthier lives, cope better with stress, and be more likely persist at difficult tasks (Baumeister, Campbell, Krueger, \& Vohs, 2003).

Keywords: sport education model, self-esteem, state sport confidence

\begin{tabular}{lr}
\hline Article History & Corresponding Author \\
Received 21 September 2020 & Hosung So \\
Accepted 15 October 2020 & hosungso@csusb.edu \\
Published 31 October 2020 & Department of Kinesiology \\
Available online 31 December 2020 & Physical Education \& Adapted Physical Education Program \\
https://doi.org/10.47544/johsk.2020.1.1.12 & California State University, San Bernardino, USA \\
\hline
\end{tabular}

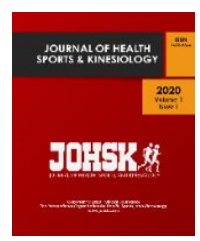

A sport-specific model of self-confidence was conceptualized into trait and state components (Vealey, 1986). The state confidence is related to a special situation or very limited time episodes (Weinberg \& Gould, 2007). Sport confidence is defined as the belief or degree of certainty individuals possess about their ability to be successful in sports. Although self-confidence and self-esteem may be related, certain individuals do not have high selfconfidence for a given activity, but still "like themselves". By contrast, there are those who may regard themselves as highly competent at a given activity but do not have corresponding feelings of self-worth (Feltz, 1988). The purpose of this study was to determine the effect of two contrasting courses on self-esteem and state sport confidence.

\section{Journal of Health Sports \& Kinesiology | ISSN 2692-9864 | www.johsk.com}


| 2020 | Volume 1 | Issue 1 | The Journal of Health, Sports, and Kinesiology |

\section{Methods}

Two intact co-educational badminton classes in a comprehensive university located in Southern California were selected for this study. A total of 49 college students (26 students in a traditional teacher-led class (GE) course and 23 kinesiology students (Pedagogy) in a sport education model course) participated and completed a survey at pre- ( $1^{\text {st }}$ week) and post-test (10 th week). The course instructor of the two intact classes had 18 years of teaching experience and a USBA certified coaching license as well as previous experience with SEM in badminton.

The Rosenberg Self-Esteem Scale (RSES; Rosenberg, 1965), consisting of 10 statements related to overall feelings of self-worth or self-acceptance on a 4-point scale (0 to 3) ranging from strongly agree (3) to strongly disagree (0) was used, scores ranging from 0 to 30 and indicating with cut-off scores of 0-15 (low self-esteem), 1525 (normal self-esteem), and 25-30 (high self-esteem). The State Sport-Confidence Inventory (SSCl; Vealey, 1986) was used to measure state sport confidence using 13 questions on a 9-point scale (low 1 to high 9), resulting in a possible score range of 13 to 117.

Due to the use of intact classes, the study utilized a nonequivalent control group design (Campbell \& Stanley, 1963), signifying the two groups may be nonequivalent prior to intervention. In the experimental condition, the SEM was delivered with a three-phase format: a teacher-directed skill development phase for 4 weeks, a preseason scrimmage phase for 2 weeks, and a formal competition phase 4 weeks. For the traditional style of instruction, the format of every lesson was similar, consisting of a 10-min warm-up followed by a 30-min skill related practice and ending with a 15-min random single or double games.

\section{Results}

Table 1 shows the means and standard deviations in student self-esteem and state sport confidence for the sport education (Pedagogy) and the traditionally taught (GE) groups before and after the intervention. The Box $M$ results indicated that the observed covariance matrices of the dependent variables were equal across groups $\left(\chi^{2}=3.09, d f=3, p=0.40\right)$. Repeated-measures ANOVA revealed no significant Group X Time interactions for selfesteem $\left[F(1,46)=3.53, p>.05, \eta^{2}=.07\right]$ and state sport confidence $\left[F(1,46)=2.42, p>.05, \eta^{2}=.05\right]$.

However, both self-esteem and state sport competence showed a significant effect on Time. There was no significant effect of SEM on sport state confidence. Effect Sizes (d) on RSES and SSCI were calculated (Cohen, 1992) and found the GE group showed a large effect size $(d=.96, p<.001)$ on the $S S C l$, whereas the Pedagogical Badminton class showed a moderate Effect Size $(d=.67, p<.01)$ on the RSES (see Figure 1).

Table 1. Means and Standard Deviations for Self-Esteem and State Sport Competence Scores at Pre- and PostIntervention

\begin{tabular}{|l|c|c|c|c|}
\hline & \multicolumn{2}{|c|}{ GE Class $(\mathbf{n}=\mathbf{2 6})$} & \multicolumn{2}{c|}{ Pedagogy Class $(\mathbf{n}=\mathbf{2 3})$} \\
\hline Measure & Pre & Post & Pre & Post \\
\hline Rosenberg Self-Esteem Score (0-30) & $19.54 \pm 4.59$ & $20.15 \pm 4.63$ & $25.27 \pm 4.75$ & $27.27 \pm 4.41$ \\
\hline State Sport Competency Score (13-117) & $68.42 \pm 21.27$ & $87.08 \pm 20.74$ & $95.65 \pm 20.56$ & $104.86 \pm 15.98$ \\
\hline
\end{tabular}

Independent sample t-tests revealed no significant differences between two classes on students' self-esteem and state sport competence prior to the intervention. However, independent sample t-tests on self-esteem $[t(46)=-5.42$, $p<.001]$ and state sport competency $[t(46)=-3.31, p<.01]$ at post-test showed significant differences. Paired-sample t-tests also revealed significant mean differences on self-esteem for the SEM class, $t(21)=-3.14, p<.01$ and state sport competency for the GE class, $t(24)=-4.80, p<.001$.

\section{Conclusion \& Discussion}

The purpose of the present study was to assess the effectiveness of a sport education curriculum model in improving self-esteem and state sport competency. Students in the sport education group reported significant pre- to postintervention increases in self-esteem, but not in the state sport competence. The results could be interpreted by Vealey's (1986) recommendations that the state sport competence is hypothesized to be positively related to performance orientation primarily focused in general college physical activity class, and negatively related to outcome orientation which is a core element of the SEM. However, self-esteem is positively related to outcome orientation (e.g., feelings of success, accomplishment, belongings, team affiliation, and formal competition).

\section{Journal of Health Sports \& Kinesiology | ISSN 2692-9864 | www.johsk.com}




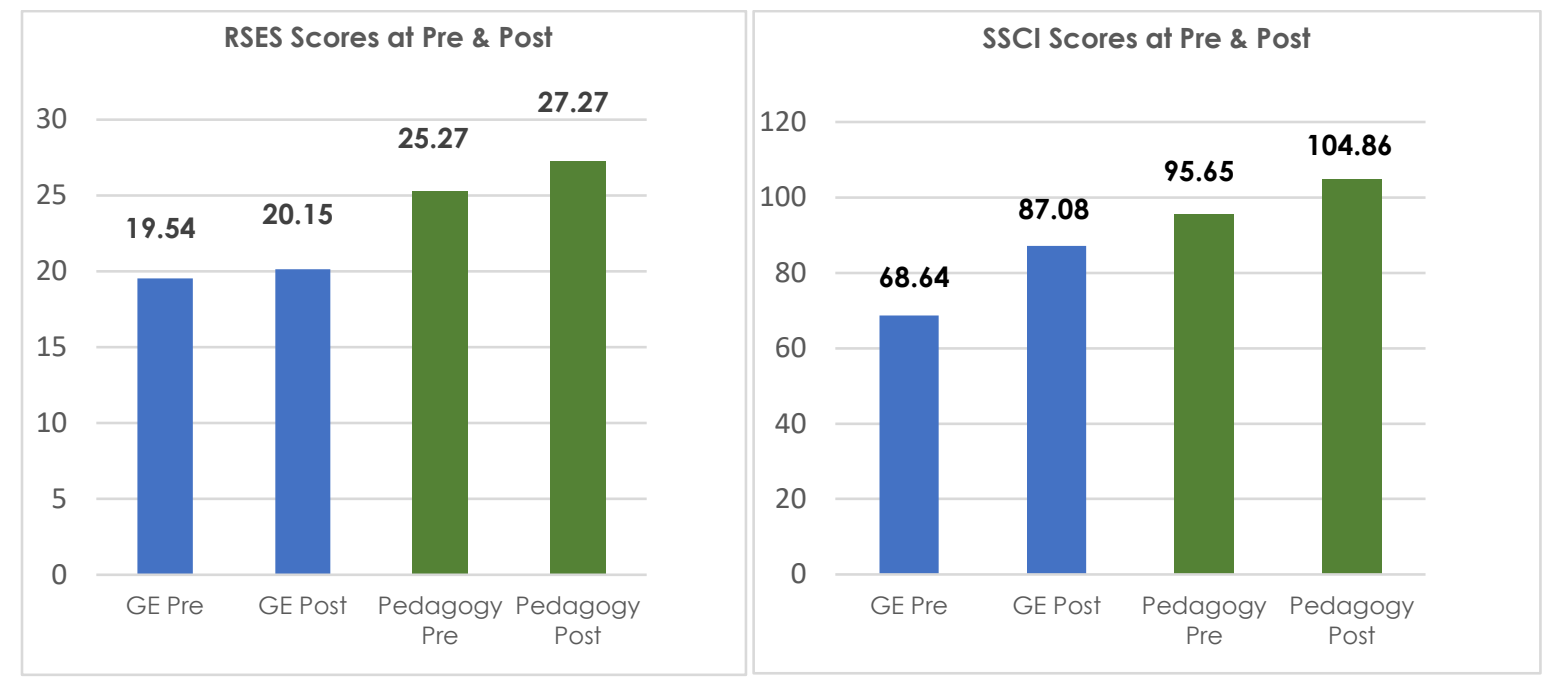

Figure 1. Scores on Rosenberg Self-Esteem and State Sport Competence at Pre and Post-Intervention in GE and Pedagogy/SEM class

Similar to Wallhead and Ntoumanis' (2004) study, although a primary goal of sport education is to develop competence in sport (Siedentop, 1994), implementation of the course SEM may indirectly affect the SEM's potential for developing student skill. The lack of significant improvement in the sport education student's state sport competence might be due to the relatively short duration of the intervention and fewer opportunities for students to practice skills in badminton that is easy to play but hard to master. Further research is required to examine the potential effect on student skill development and perceptions of competence in the sport education courses.

\section{References}

Alexamder, K., \& Luckman, J. (2001). Australian teachers' perceptions and uses of the sport education curriculum model. European Physical Education Review, 7(3), 243-267.

Baumeister, R. F., Campbell, J. D., Krueger, J. I., \& Vohs, K. D. (2003). Does high self-esteem cause better performance, interpersonal success, happiness, or healthier lifestyles? Psychological Science in the Public Interest, 4, 1-44.

Campbell, D. T., \& Stanley, J. C. (1963). Experimental and quasi-experimental designs for research. Reprinted from N. L. Gage (Ed.), Handbook of research on teaching. Boston: Rand McNally.

Cohen, J. (1992). A power primer. Psychological Bulletin, 112(1), 155-159.

Feltz, D. L. (1988). Self-confidence and sports performance. Exercise and Sport Science Review, 16, 423-457.

Rosenberg, M. (1965). Society and the adolescent self-image. Princeton, NJ: Princeton University Press.

Schacter, D. L., Gilbert, D. T., \& Wegner, D. M. (2009). Personality. New York: Worth Publisher.

Siedentop, D. (1994). Sport Education: Quality P.E. through positive sport experiences. Champaign, IL: Human Kinestics.

Siedentop, D., Hastie, P., \& van der Mars, H. (2020). Complete guide to sport education (3rd ed.). Champaign, IL: Human Kinetics.

Vealey, R. S. (1986). Conceptualization of sport confidence and competitive orientation: Preliminary investigation and instrument development. Journal of Sport Psychology, 8, 221-246.

Wallhead, T., \& Ntoumanis, N. (2004). Effects of a sport education intervention on students' motivational responses in physical education. Journal of Teaching in Physical Education, 23, 4-18.

Journal of Health Sports \& Kinesiology | ISSN 2692-9864 | www.johsk.com 
| 2020 | Volume 1 | Issue 1 | The Journal of Health, Sports, and Kinesiology |

Weinberg, R. S., \& Gould, D. (2007). Foundations of sport and exercise psychology, Champaign, IL: Human Kinetics. Weinberg, R. S., \& Williams, J. M. (1993). Integrating and implementing a psychological skills training program. In J. M. Williams (Ed.), Applied Sport Psychology. Mountain View, CA: Mayfield. original work is properly cited. 